\title{
Reductive dissolution and metal transport in Lake Coeur d'Alene sediments
}

\author{
S.S. Sengor ${ }^{1}$, N.F. Spycher ${ }^{2}$, T.R. Ginn ${ }^{1}$, J. Moberly ${ }^{3}$, B. Peyton ${ }^{3}$, R.K. Sani ${ }^{4}$ \\ ${ }^{1}$ University of California, Civil and Environmental Engineering Department, Davis, CA, USA \\ ${ }^{2}$ Earth Sciences Division, Lawrence Berkeley National Laboratory, Berkeley, CA, USA \\ ${ }^{3}$ Montana Sate University, Chemical and Biological Engineering Department, Bozeman, MT, USA \\ ${ }^{4}$ South Dakota School of Mines and Technology, Chemical and Biological Engineering Department, \\ Rapid City, SD, USA
}

\begin{abstract}
The benthic sediments in Lake Coeur d'Alene, northern Idaho, have been contaminated by metals (primarily $\mathrm{Zn}, \mathrm{Pb}$, and $\mathrm{Cu}$ ) from decades of upstream mining activities. As part of ongoing research on the biogeochemical cycling of metals in this area, a diffusive reactive-transport model has been developed to simulate metal transport in the lake sediments. The model includes 1-D inorganic diffusive transport coupled to a biotic reaction network with multiple terminal electron acceptors under redox disequilibrium conditions. Here, the model is applied to evaluate the competing effects of heavy-metal mobilization through biotic reductive dissolution of $\mathrm{Fe}(\mathrm{III})$ (hydr)oxides, and immobilization as biogenic sulfide minerals. Results indicate that the relative rates of $\mathrm{Fe}$ and sulfate reduction could play an important role in metal transport through the environment, and that the formation of (bi)sulfide complexes could significantly enhance metal solubility, as well as desorption from Fe hydroxides.
\end{abstract}

\section{INTRODUCTION}

The rich mining history of the Western United States, which began in the late 1880's, has left many sites contaminated with toxic metals including $\mathrm{Zn}$, $\mathrm{Pb}$, and $\mathrm{Cu}$. One example is Lake Coeur d'Alene, located in northern Idaho, where lake sediments have been impacted by decades of contaminated runoff into the Lake Coeur d'Alene River, mainly from the Bunker Hill Superfund mining site.

The weathering and oxidation of sulfide minerals associated with exposed ore and mine tailings results in acid waters containing high concentrations of dissolved $\mathrm{SO}_{4}, \mathrm{Fe}, \mathrm{Mn}$, and other pollutant metals. Upon mixing of this acid mine drainage with nearneutral surface waters, insoluble precipitates are typically observed to form, mainly in the form of $\mathrm{Fe}$ and Mn (hydr)oxide phases. In the Coeur d'Alene mining district, it has been shown that dissolved heavy metals sorb onto these newly formed Fe and Mn (hydr)oxide particles, resulting in a significant concentration decrease in surface waters (Tonkin et al., 2002; Balistrieri et al., 2003). Analysis of these particles in the lower Lake Coeur d'Alene River valley show that these particles are associated with significant amounts of amorphous and nanocrystalline phases (Balistrieri et al., 2002). These (hydr)oxide particles are likely to be transported in surface waters over very large distances. This process, along with the transport of detrital primary sulfide minerals, could significantly contribute to the transport of metals away from mining areas. In the case of Lake Coeur d'Alene, there has been controversy over whether metals in the sediments are primarily associated with iron oxides (Horowitz et al., 1995, 1999) or a sulfidic phase (Harrington et al., 1998, 1999). Recent spectroscopic data point to abundant ferrihydrite and high Fe-to-S ratios in the sediments (Toevs et al., 2006), providing further support that metal transport to the lake could occur primarily as sorbed species onto Fe(III) (hydr)oxides.

We have developed a diffusive reactive transport model to simulate the benthic transport and fate of $\mathrm{Zn}, \mathrm{Pb}$, and $\mathrm{Cu}$ in benthic Lake Coeur d'Alene sediments (Sengor et al., 2007), in order to evaluate the mobilization of heavy metals sorbed onto hydrous $\mathrm{Fe}(\mathrm{III})$ oxides by means of microbial reductive dissolution (e.g., Zachara et al., 2001), and competing effects of metal precipitation as biogenic sulfide minerals. Here, we further investigate the role of metal (bi)sulfide complexes in potentially enhancing metal solubility and desorption from ferrihydrite.

\section{NUMERICAL MODEL}

Details on the numerical model and input data are provided in Sengor et al. (2007). The 1-D model was 
developed using PHREEQC (Parkhurst and Appelo, 1999), with key aspects summarized below.

\subsection{Inorganic reaction system}

The modeled inorganic reaction processes include aqueous speciation, surface complexation onto $\mathrm{Fe}$ hydroxides (as ferrihydrite), and mineral precipitation/dissolution reactions. Reactive minerals considered in the model are ferrihydrite (as $\mathrm{Fe}(\mathrm{OH})_{3}$ ), as primary mineral, and siderite $\left(\mathrm{FeCO}_{3}\right)$, disordered mackinawite $\left(\mathrm{FeS}_{\mathrm{m}}\right)$, sphalerite $(\mathrm{ZnS})$, galena $(\mathrm{PbS})$, and chalcocite $\left(\mathrm{Cu}_{2} \mathrm{~S}\right)$, as secondary phases. The model conceptualization is based on the analyses of sediments, pore waters and surface waters from Lake Coeur d'Alene and the Coeur d'Alene River, conducted mostly by Winowiecki, (2002), Toevs et al., (2006), Balistrieri et al., (1998, 1999, 2003), and Cummings et al., (2000).

\subsection{Microbially mediated reaction system}

The inorganic reaction system is coupled to a microbially mediated reaction network with microbial consortium biodegradation kinetics involving multiple terminal electron acceptors. The terminal electron acceptors included are $\mathrm{O}_{2}, \mathrm{NO}_{3}{ }^{-}, \mathrm{Fe}(\mathrm{III})$, and $\mathrm{SO}_{4}{ }^{-2}$, and redox is decoupled in the reaction network. Note that although the Mn content of sediments is elevated, it is 10 times lower than the Fe content. For this reason, the effect of Mn reduction is currently neglected and sorption is assumed to be controlled by Fe hydroxides alone. Acetate is used as the ultimate energy source, because it is a common end-product of many fermentation processes and can be utilized by many metal- and sulfatereducing bacteria in sediments (Lovley 2002). Single Michaelis-Menten kinetics is used to represent the biodegradation of acetate (non limiting) with concomitant reduction of terminal electron acceptors. The sequential utilization of the terminal electron acceptors is implemented using inhibition factors (Van Cappellen \& Gaillard, 1996) to impede the lower Gibb's free-energy biotic-redox reactions when higher Gibb's free-energy electron acceptors are available.

\section{MODEL RESULTS}

The model simulates the diffusion of oxic lake water into a 1-D sediment column (from the top down), initially under oxic conditions throughout. Sorbed heavy metals are included on the surface of ferrihydrite. As oxygen and subsequent electron acceptors are consumed, ferrihydrite and aqueous sulfate progressively reduce to aqueous Fe(II) and sulfide species, respectively. The model is run for periods of 2 and 5 years, after which near-steady-state conditions develop. Additional cases without sulfate-reducing bacteria (SRB) and without metal (bi)sulfide aqueous species are also run.

\subsection{Mobilization of metals and $\mathrm{pH}$ trends}

The model results show that the relative rates of $\mathrm{Fe}(\mathrm{III})$ reduction versus sulfate reduction may be a key factor controlling the mobilization of heavy metals, $\mathrm{pH}$, and the relative amounts of Fe(II) mineral precipitation with depth. It is observed that the reductive dissolution of ferrihydrite promotes the release of sorbed metals into the pore water (Figs. 1 \& 2 ). As the metal sulfide precipitation occurs, dissolved heavy metal concentrations sharply decrease, yielding computed concentrations closer to measured values (Figs. 1 \& 2). Such concentration drop at depth has also been reported by others for iron and heavy metals (e.g., Huerta-Diaz et al., 1998).

Modeled $\mathrm{pH}$ values show an initially increasing trend with depth, followed by slowly decreasing values further down in the anoxic zone (Fig. 3). The initial increase with depth is controlled by the reductive dissolution of ferrihydrite, which drives $\mathrm{pH}$ up, as shown by: $8 \mathrm{Fe}(\mathrm{OH})_{3(\mathrm{~s})}+\mathrm{CH}_{3} \mathrm{COOH}+14 \mathrm{H}^{+}<=>$ $8 \mathrm{Fe}^{+2}+2 \mathrm{HCO}_{3}{ }^{-}+20 \mathrm{H}_{2} \mathrm{O}$. The modeled $\mathrm{pH}$ reversal at a depth of about $10 \mathrm{~cm}$ can be explained by the precipitation of $\mathrm{Fe}(\mathrm{II})$ sulfide, as illustrated by: $\mathrm{Fe}^{+2}$ $+2 \mathrm{CH}_{3} \mathrm{COOH}+\mathrm{SO}_{4}^{-2}<=>8 \mathrm{FeS}_{\mathrm{m}(\mathrm{s})}+2 \mathrm{HCO}_{3}^{-}+$ $2 \mathrm{H}_{2} \mathrm{O}+2 \mathrm{H}^{+}$. The competitive effects of these reactions on $\mathrm{pH}$, is also illustrated by the model results shown for both "high" and "low" rates of Fe(III) reduction, using the same rate of sulfate reduction in both cases. When the $\mathrm{Fe}(\mathrm{III})$ reduction rate is lowered, the rise in $\mathrm{pH}$ (caused by the $1^{\text {st }}$ reaction) is less pronounced, and the decrease in $\mathrm{pH}$ (caused by the $2^{\text {nd }}$ reaction) is more pronounced (Fig. 3). Consistent with these reactions, when the model is run without SRB activity, $\mathrm{pH}$ shows a further increasing trend (Fig. 3) resulting from the lack of sulfide production, and hence, lack of Fe(II) sulfide precipitation. The $\mathrm{pH}$ increase in this case further stabilizes surface complexes and increases the net sorption of heavy metals onto ferrihydrite, despite the ongoing microbial reductive dissolution. The net effect, in this case without SRB, is that the dissolved heavy metal concentrations decrease with time and depth (Figs. 1 \& 2), illustrating the complex coupling and competitive nature of processes at play.

\subsection{Aqueous complexation with biogenic sulfide}

Model results show that the majority of the dissolved heavy metals are in the form of (bi)sulfide complexes, and the majority of the aqueous sulfide consists of $\mathrm{Pb}, \mathrm{Zn}, \mathrm{Cu}$ (bi)sulfide species, and $\mathrm{FeS}_{(\mathrm{aq})}$ (Fig. 4). When heavy-metal (bi)sulfide complexes are not allowed to form, the model indicates that $\mathrm{FeS}_{(\mathrm{aq})}$ becomes the main aqueous sulfide species, 


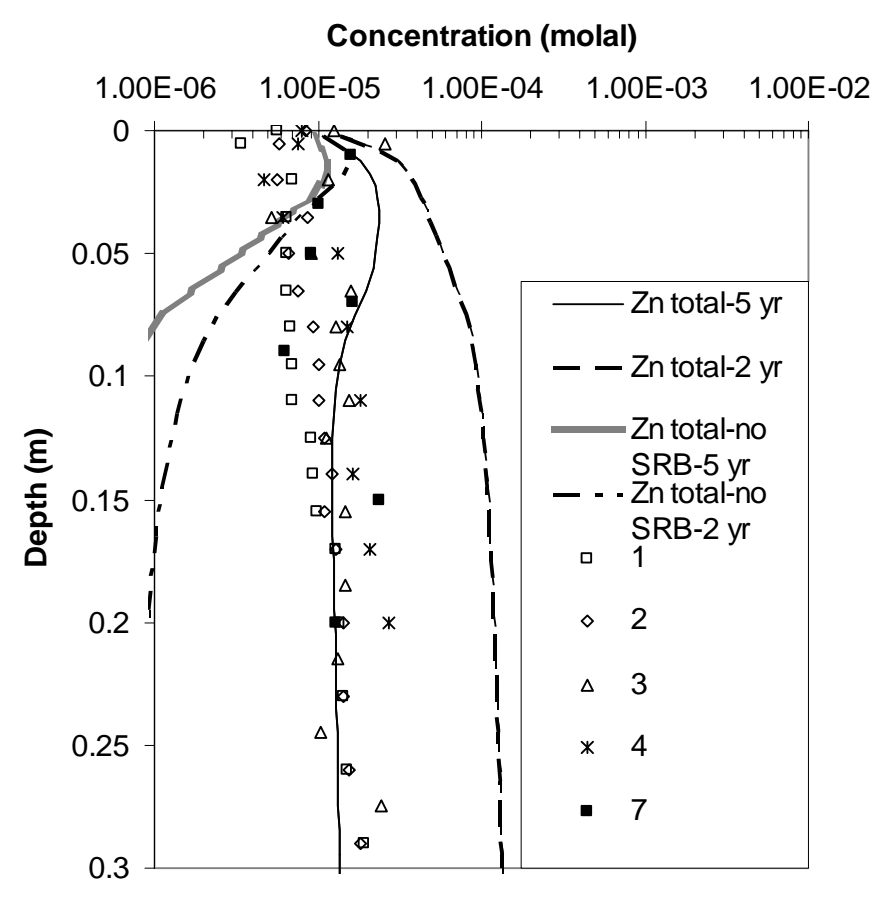

Figure 1. Zn concentration profile with depth: comparison of model predictions (lines, 5 and 2-year results, with and without the activity of SRB) with measured concentrations (symbols, data source: ${ }^{1-6}$ Winowiecki (2002), Site A, 2001: ${ }^{1,2}$ Summer, ${ }^{3,4}$ Spring, ${ }^{5,6}$ Fall; ${ }^{7}$ Balistrieri (1998), September 2002, Delta Site; ${ }^{8}$ Toevs et al., (2006), May 2002, Harlow Point).

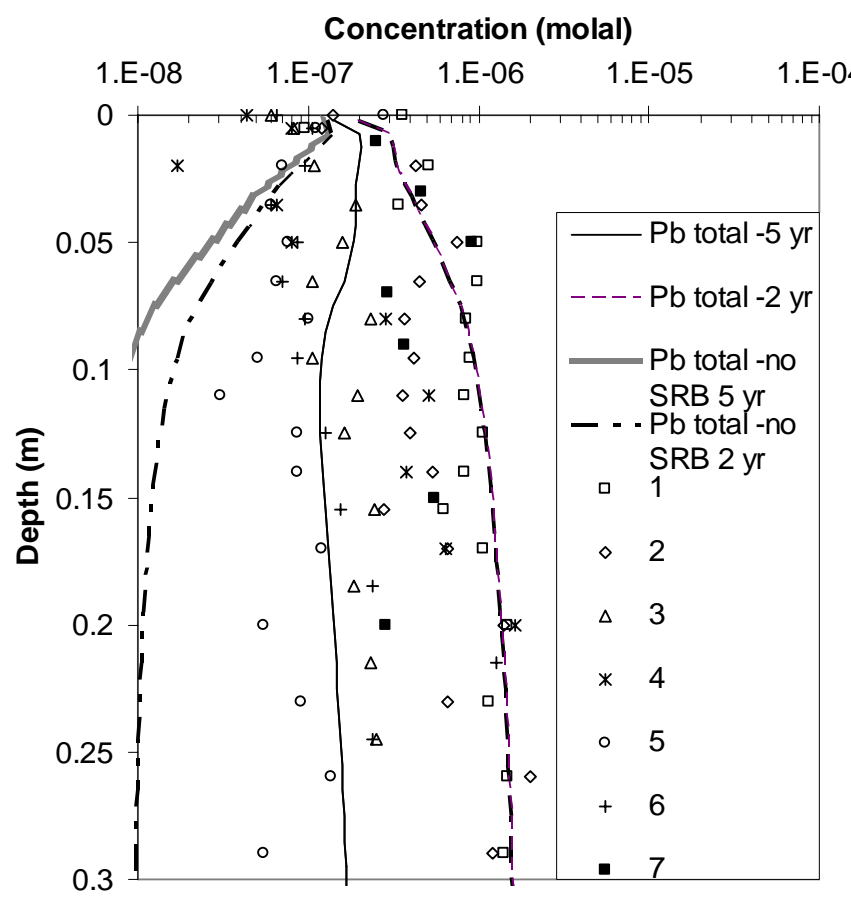

Figure 2. Pb concentration profile with depth: comparison of model predictions (lines, 5 and 2-year results, with and without the activity of SRB) with measured concentrations (symbols, see caption of Figure 2 for data sources).

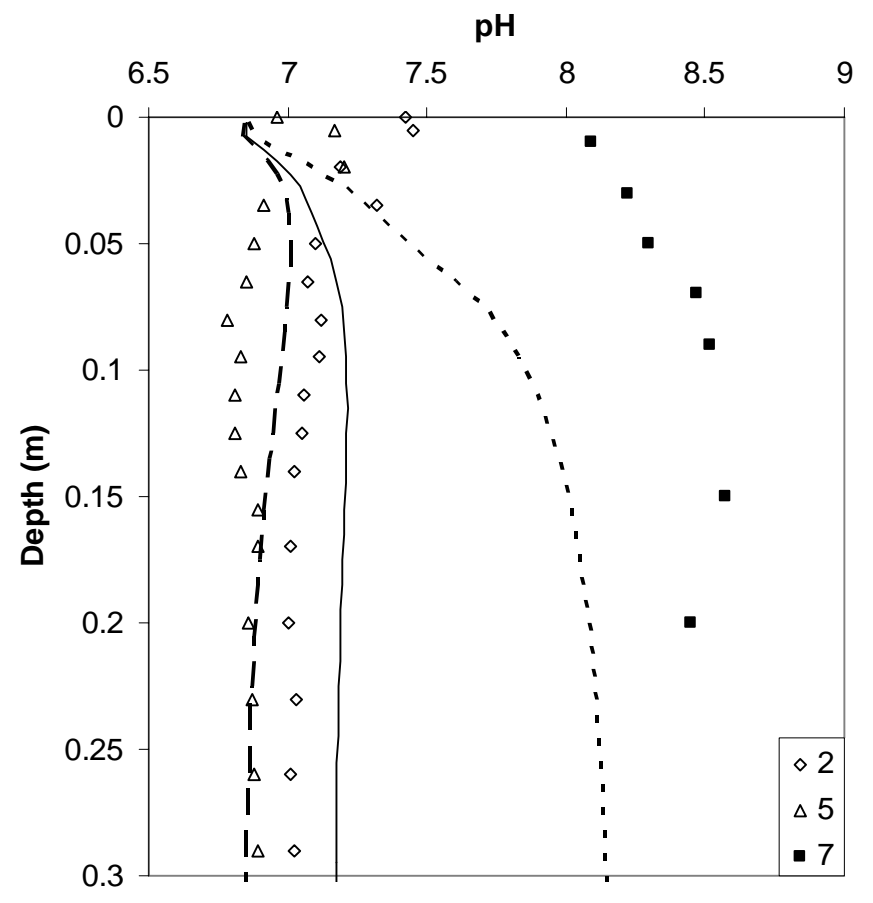

Figure 3. pH profile with depth: comparison of model predictions (lines, 5-year results) for "high" (solid line), "low" (dashed line) Fe(III) reduction rate, and "high" Fe(III) reduction without the activity of SRB) (dotted line) with measured concentrations (symbols, see caption of Figure 2 for data sources).

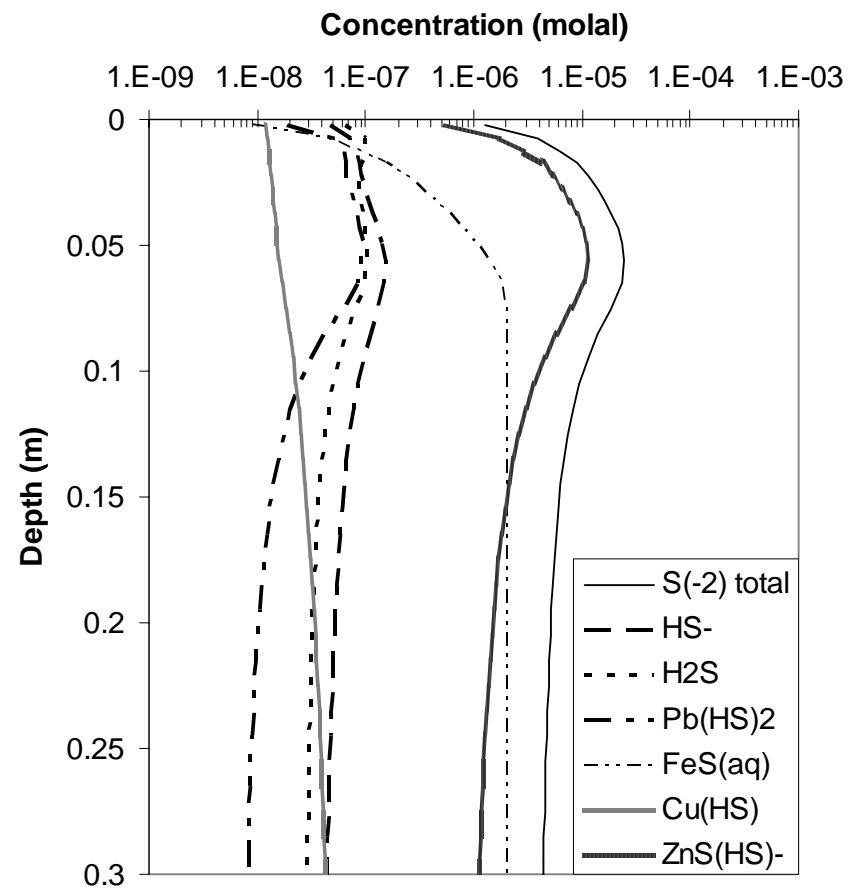

Figure 4. Calculated distribution of aqueous sulfide species. The bulk of dissolved sulfide is computed to occur as metal (bi)sulfide complexes. 
and that the total dissolved metal concentrations decrease compared to the case with all sulfide species. This indicates that the strong metal (bi)sulfide complexes can significantly enhance metal solubility as well as desorption from Fe(III) (hydr)oxides.

\subsection{Mineral precipitation}

The two major sinks for dissolved Fe(II) in the system are $\mathrm{FeS}_{\mathrm{m}}$ and $\mathrm{FeCO}_{3}$. The biogeochemical system forms a delicate balance, with $\mathrm{FeS}_{\mathrm{m}}$ competing with $\mathrm{FeCO}_{3}$ precipitation for $\mathrm{Fe}(\mathrm{II})$, and the competition of aqueous (bi)sulfide complexes and sulfide mineral precipitation for biogenic sulfide.

\section{CONCLUSIONS}

This study focuses on the hypothesis that the bulk of metals in Lake Coeur d'Alene sediments are initially associated with Fe(III) (hydr)oxides, and their mobilization occur primarily through reductive dissolution. Authigenic sulfide mineral formation as a result of the coupling of inorganic and microbiological processes is also considered. The model is congruent with the observations by Cummings et al. (2000), Balistrieri et al. (2002, 2003), Winowiecki (2002), and Toevs et al. (2006). The model does not preclude the presence of detrital sulfide minerals, but indicates that the trends of dissolved metal concentrations can be explained by reductive dissolution of Fe(III) (hydr)oxides and biogenic sulfide mineral formation.

The relative rates of Fe(III) versus sulfate reduction is observed to be a key factor controlling $\mathrm{pH}$ and the mobility of heavy metals sorbed onto Fe(III) oxide phases. Microbial reductive dissolution of ferrihydrite promotes the solubilization of metals, whereas precipitation of heavy-metal sulfides sharply decreases the dissolved metal concentrations. Decrease in the rate of sulfate reduction results in an increase in the $\mathrm{pH}$ trend, because of the decrease in the precipitation of $\mathrm{Fe}(\mathrm{II})$ sulfides with depth, which then results in an increased sorption of heavy metals onto Fe(III) (hydr)oxides and an overall decrease in mobilization. It is observed that dissolved metals form strong metal (bi)sulfide complexes, which also further enhances their desorption from ferrihydrite. A delicate balance is observed to exist between the effects of $\mathrm{FeS}_{\mathrm{m}}$ and siderite precipitation. The effects of Fe(III) reduction relative to sulfate reduction are currently being further investigated through controlled laboratory experiments.

\section{REFERENCES}

Balistrieri, L.S., Box, S.E., Bookstroom, A.A., Hooper, R.L., \& Mahoney, J.B., 2002. Impacts of historical mining in the
Coeur d’Alene Basin. In: Balistrieri, L.S. and Stillings, L.L. (Eds.), Pathways of Metal Transfer from Mineralized Sources to Bioreceptors: A Synthesis of the Mineral Resources Program's Past Environmental Studies in the Western United States and Future Research Directions, U.S. Geological Survey Bulletin 2191, pp. 1-34 (Chapter 6).

Balistrieri, L.S., Box, S.E., \& Tonkin, J.W., 2003. Modeling precipitation and sorption of elements during mixing of river water and porewater in the Coeur d'Alene River Basin. Environ. Sci. Technol. 37, 4694-4701.

Cummings,D.E., March, A.W., Bostick, B.C., Spring, S., Caccavo, F., Jr., Fendorf, S., \& Rosenzweig, R.F., 2000. Evidence for microbial Fe(III) reduction in anoxic, mining impacted lake sediments (Lake Coeur d'Alene, Idaho). Appl. Environ. Microbiol. 66, 154-162.

Huerta-Diaz,M.A.,Tessier,A., Carignan, R., 1998. Geochemistry of trace metals associated with reduced sulfur in freshwater sediments. Appl. Geochem. 13, 213-233.

Harrington, J.M., La Force, M.J., Rember, W.C., Fendorf, S. E., \& Rosenzweig, R.F., 1998. Phase associations and mobilization of iron and trace elements in Coeur d'Alene Lake, Idaho. Environ. Sci. Technol. 32, 650-656.

Harrington, J.M., Fendorf, S. E., Wielinga, B.W., \& Rosenzweig, R.F., 1999. Response to comments on: "Phase associations and mobilization of iron and trace elements in Coeur d'Alene Lake, Idaho”. Environ. Sci. Technol. 33, 203-204.

Horowitz, A.J., Elrick, K.A., Robbins, J.A., \& Cook, R.B., 1995. Effect of mining and related activities on sediment trace element geochemistry of Lake Coeur D’Alene, Idaho, USA Part II. Subsurface sediments. Hydrol. Process. 9, 3554.

Horowitz, A.J., Elrick, K.A., \& Cook, R.B., 1999. Comments on: "Phase associations and mobilization of iron and trace elements in Coeur d'Alene Lake, Idaho”. Environ. Sci. Technol. 33, 201-202.

Lovley D.R., 2002. Dissimilatory metal reduction: from early life to bioremediation. ASM News 68(5):231-237

Parkhurst, D.L. \& Appelo, C.A.J., 1999. User's Guide to PHREEQC (Version 2)-a computer program for speciation, batch-reaction, one-dimensional transport, and inverse geochemical calculations. Water-Resources Investigations Report 99-4259; U.S. Geological Survey, Denver, CO.

Sengor, S.S., Spycher, N.F., Ginn, T.R., Sani, R.K., \& Peyton, B., 2007. Biogeochemical reactive-diffusive transport of heavy metals in Lake Coeur d'Alene sediments. Applied Geochemistry (in press).

Toevs, G.R., Morra, M.J., Polizzotto, M.L., Strawn, D.G., Bostick, B.C., \& Fendorf, S., 2006. Metal(loid) diagenesis in mine-impacted sediments of Lake Coeur d'Alene, Idaho. Environ. Sci. Technol. 40, 2537-2543.

Tonkin, J.W., Balistrieri, L.S., \& Murray, J.W., 2002. Modeling metal removal onto natural particles formed during mixing of acid rock drainage with ambient surface water. Environ. Sci. Technol. 36, 484-492.

Van Cappellen, P. \& Gaillard,P., 1996.Biogeochemical dynamics in aquatic sediments. In: Lichtner, P. C.,Steefel, C. I., Oelkers, E. H. (Eds.), Reactive Transport in Porous Media, vol. 34. Mineralogical Society of America, pp. 335376 (Chapter 8).

Winowiecki, L., 2002. Geochemical cycling of heavy metals in the sediment of Lake Coeur d'Alene, Idaho. Masters Thesis, University of Idaho, Moscow, Idaho.

Zachara, J.M., Fredrickson, J.K., Smith, S.C., Gassman P.L., 2001. Solubilization of Fe(III) oxide-bound trace metals by a dissimilatory $\mathrm{Fe}(\mathrm{III})$ reducing bacterium. Geochimica et Cosmochimica Acta 1, 75-93. 